\title{
Study of the Hydroponic Barley Effect on the Performance of Feedlot of Calves in the Region Souss Massa (Southern Morocco)
}

\author{
Bari Samir $^{1,2^{*}} \quad$ Abbassi Mohammad $^{1,4} \quad$ Aboudlou Leila $^{1} \quad$ Nadir Maryem $^{1,6} \quad$ El Moukhtari Mounaim ${ }^{3}$ \\ Mannas Hasna $^{2}$ Assabbane Ali ${ }^{5}$ Ait Ichou Ihya ${ }^{5}$ Kaya Abderrazak ${ }^{1}$ \\ 1.Bio Environment, Health and Bioresources Team, Ibn University Zohr, Department of Biology, Faculty of \\ Sciences, Ibn Zohr University, BP 28/S, Agadir, Morocco \\ 2.Regional Office for Agricultural Development of Souss Massa, Public Administration Street, BP 21, Agadir, \\ Morocco \\ 3.Souss Cooperative of Bovine Genetic Improvement, COPAG, Taroudant, Morocco \\ 4.Suprior Institute of Maritime Fishing, BP 479, Agadir, Morocco \\ 5.Laboratory LACAPE, Department of Chemistry, Faculty of Sciences, Ibn Zohr University, BP 28/S, Agadir, \\ Morocco \\ 6.Laboratory of "Aquatic Systems: Marin and continental field", Department of Biology, Faculty of Sciences, \\ Ibn Zohr University, BP 28/S, Agadir, Morocco. \\ "E-mail oh the corresponding author: barisamir@gmail.com
}

\begin{abstract}
The objective of this research is to investigate the effect of the introduction of hydroponic barley; produced as feed supplement in the ration, on the performance of feedlot calves. This study was performed in the Taroudant region (South of Morocco), during a trial period between July and October 2017). A total of 100 calves were used in a feeding trial, which were divided into two groups. The calves of the first group received a total mixed ration (control), while the calves of the second group received a similar ration with the addition of hydroponic barley.Similar growth performance is observed for the two groups, which is easily explained by the equivalent rationing. In the finishing phase, however, a higher average daily gain is observed for the group fed with an enriched diet in hydroponic green fodder. In fact, the average daily gain for this group amounts to $1.48 \mathrm{Kg} / \mathrm{Day}$ compared to $1.42 \mathrm{Kg} /$ Day for the control group.The slaughter results confirm those noted in terms of growth performance, with a relatively similar carcass yield for the two groups.However, since hydroponic fodder reveals a positive impact especially at the level of the finishing phase, it seems judicious to introduce it in the key phases of fattening and finishing in order to perfect the weight gain of the species benefiting from this contribution.The test results suggest that hydroponic barley based rationing is to deepen, and that it would be desirable to repeat the experiment by testing different levels of hydroponic barley intake, adjusting both the type and the level of complementation, with a more accurate monitoring of feeding.
\end{abstract}

Keywords: Feedlot calves; Growth, Hydroponic barley, Performance,

DOI: $10.7176 / \mathrm{JBAH} / 11-14-05$

Publication date:July $31^{\text {st }} 2021$

\section{1- Introduction}

Green fodder is an essential component of the livestock ration, used to improve their production and reproduction performance. Therefore, to improve livestock products, quality green fodder should be given more often to animals (Dung et al., 2010). This type of forage is considered the backbone of dairy sector in reason of its vital role in valorization of dairy farming to profitable business (Kumar et al., 2019).

In recent years, hydroponics are seen as a promising strategy for growing different crops (Sharma et al. 2019). However, various constraints are faced by the farmers for the production of green fodder in the Souss Massa plain. Factors such as small land holdings, unavailability of land for fodder cultivation, scarcity of water or saline water, the semi-arid climate of the region (with more than 3,000 hours of sunshine), the increasingly frequent droughts, and the exponential overexploitation of the table water, could hinders the growth of livestock and could consequently, this deficit limits any increase in the yield of animals.

Furthermore, the non-availability of constant quality of fodder during the year aggravates the limitations of the sustainable dairy farming. This forces the farmers to use excessively the concentrate which is an expensive food. As a result, prices of animal products such as meat and milk are continuously rising, affecting the consumers' purchasing power.

One of the alternatives to meet this increasing demand for green fodder is the use of hydroponic fodder to supplement the meager pasture resource. This technique can improve the forage potential including hydroponics, and can produce a forage quality, which is appreciated by animals. Hydroponic allows a farmer to grow plants more efficiently and productively with less labor and time.

Today, hydroponics are used in harsh climates such as deserts, areas with poor soil or in urban areas where high land costs have driven out traditional agriculture (Bakshi et al., 2017). It was adopted in several countries 
that have faced this type of problems such as Latin America, Australia, Europe, and recently the Middle East where this technique has been a great success.

Indeed, thanks to the hydroponic culture, we can produce a guaranteed quantity of $100 \%$ natural green fodder, on a very small surface, and in various climatic conditions. This method of forage production has many benefits for the farmer, economy, and environment. Limited research has been conducted to determine the nutritional value of hydroponically sprouted kernels (Peer and Lesson, 1985). Hydroponic culture is considered as a substitute to concentrates and green fodder and it reduces the cost of production and increases the milk and meat production in livestock in drought prone areas and where there is less availability of green fodder (Indira $e t$ al., 2020). In addition, hydroponic fodder is known for its potential benefits for the health of the herd (Sneath and Mcintosh, 2003).

A wide range of tests to evaluate the performance of livestock on beaks have been conducted globally, and these researches has shown an increase in animal performance on hydroponic fodder, which they deposit to a grass juice factor. This is supported by Finney (1982), Chavan and Kadam (1989), Sneath and Mclntosh (2003) and Shipard (2005) who showed that hydroponic fodders are a good source of chlorophyll, and contain a grass juice factor that improves the livestock performance.

This article follows on from the study conducted by Bari et al. (2020) to determine the effect of introducing green hydroponic fodder at $30 \%$ of the theoretical forage requirement in the daily ration, on the consumption and performance of lambs. This study shows higher growth performance in the test batch. In addition, this study reported the effect of hydroponic Barley diet on the productive performance of goats, highlights faster growth performance following the consumption of hydroponic barley by males (up to $30 \%$ ) and females (up to $38 \%$ ) at different ages.

All data mentioned above clearly shows that hydroponic barley is emerging as an advantageous alternative for farmers wishing to increase and boost the performance of their goat livestock and the financial structure and performance of a cooperative (Bari et al., 2019).

In the logical continuation of our previous work mentioned above, our study aims to determine the effect of the introduction of hydroponic barley, produced as a food supplement in the ration, on the performance of feedlot calves.

\section{2- Materials and Methods}

\section{2-1 Study site}

The test takes place at a feedlot of the Agricultural Cooperative (COPAG) located in Ait Iazza in the province of Taroudant (South of Morocco) (Figure 1) and designed according to the model of American "feedlots", with a main objective of fattening young bull calves according to economies of scale.

This feedlot, backed by a slaughterhouse as part of an integrated project, includes fattening workshops, slaughterhouse, cutting room, and delicatessen. Its capacity amounts to 12000 heads of different ages and weights, to ensure a continuous supply of the slaughterhouse.

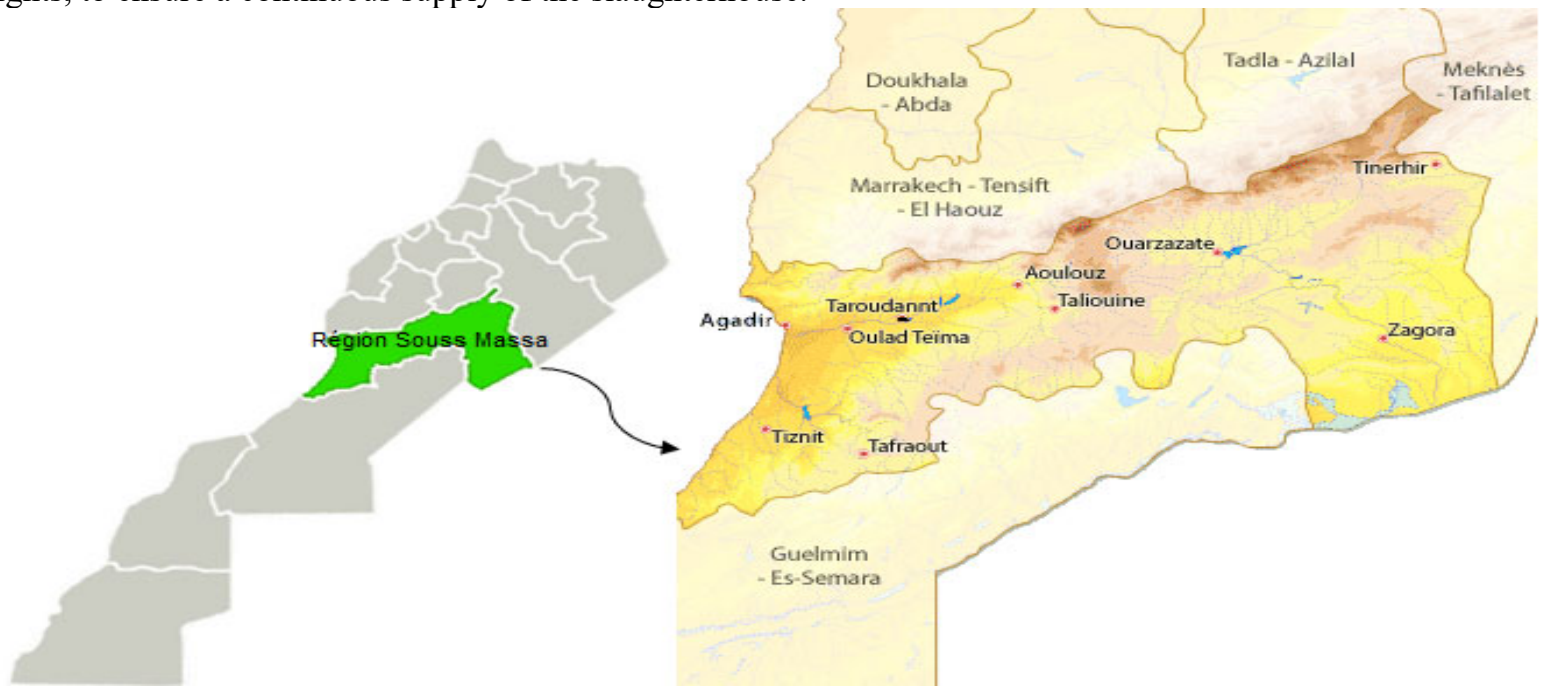

Figure 1: Map showing the location of the Province of Taroudant in the Souss Massa Region

\section{2-2 Hydroponic barley production}

The used Hydroponic Barley (HB) is obtained from malting barley seeds (local variety, with 90\% germination rate). The used seeds are first cleaned and disinfected with sodium hypochlorite $(1 \mathrm{ml} / \mathrm{l})$. After being rinsed with potable water, the seeds are soaked in fresh water for 16 to 18 hours, and then drained before being sown for 
cultivation at a density of $7 \mathrm{Kg} / \mathrm{m} 2$. The culture takes place in a closed chamber (Model E-12-TX), with an area of $92 \mathrm{~m} 2$. Temperature, humidity, and lighting are controlled $\left(18 \pm 1.5^{\circ} \mathrm{C}, 60-100 \% \mathrm{H}\right.$, and 12 hours a day (58W fluorescent lamps) respectively). The culture is irrigated by immersion twice a day ( $2 \pm 0.11 / \mathrm{Kg} \mathrm{Raw}$ Material). The harvest is carried out at the seedling stage at $7 \pm 1$ day. The generally observed yield is $6.01 \pm$ $0.10 \mathrm{Kg}$ of green fodder, produced per $\mathrm{Kg}$ of dry germinated grain at $12-13.5 \%$ dry matter.

\section{2-3 Performed Analyses}

Samples of the two rations used in our test were collected and dried in an oven at $70{ }^{\circ} \mathrm{C}$ for 48 hours, and then weighed before being analyzed. We have adopted the analytical methods recommended by AOAC 2000 (Association of Official Analytical Chemists) and also by FAO). A global analysis of the collected samples was performed and the total nitrogen content (TNC) was determined.

The contents of crude protein, mineral matter (phosphorus and calcium), dry matter (DM), acidic detergent fibers (ADF), and neutral detergent fibers (NDF) were also defined both in the control batch and in the batch comprising the hydroponic green fodder (Robertson and Van Soest, 1981; Pandey et al., 1991; Van Soest et al., 1991; Gebremedhin et al., 2015) (Table 1).

\section{2-4 Measurements made on animals}

The test involves a total of 100 bull calves of the Holstein breed. At the start of the test, we see an average weight of $296 \mathrm{Kg}$ and an average age of 290 days. This overall sample is divided into two batches of 50 animals each, which were kept in free stalls. Each batch was assigned at random to one of the following regimes: Control and Test.

A comparison of these fattening diets made up of wheat straw and corn silage was done. The two batches received respectively: $i)$ wheat straw, corn silage and concentrate for cattle, according to the breeder's practices for the control batch and ii) wheat straw, corn silage and concentrate for cattle added of $21 \%$ of the theoretical fodder requirements in the form of hydroponic green barley fodder of $7 \pm 1$ days, for HB batch.

It should be noted that wheat straw and corn silage are supplied at will. However, the concentrate is rationed according to the usual practices of the breeder, at an equivalent dose for the two batches. Hydroponic barley is added in addition to the basic "straw and concentrate" ration, as a feed supplement.

The description of the foods characteristics and the design of experimental diets meets the technical requirements of the slaughterhouse in terms of nutrients, namely: $1700 \mathrm{~g} / \mathrm{d}^{-1}$ (Table 1).

The animals were dewormed at the start of the trial, and also after one month. They were also weighed at the entry and exit of the test, as well as once every two months during the experiment period.

The carried-out tests extend over a period of 175 days, preceded by an adaptation period of 15 days in order to accustom the animals to the food rations. The rations delivered at will are divided into two meals per day. Also water and sodium chloride blocks were available at will.

Table 1: Foods characteristics for the control and hydroponic barley rations

\begin{tabular}{|c|c|c|c|c|}
\hline \multirow{3}{*}{ Ingredients/Characteristics } & \multicolumn{4}{|c|}{ Dietary groups } \\
\hline & \multicolumn{2}{|c|}{ Hydroponic Barely Ration } & \multicolumn{2}{|c|}{ Control Ration } \\
\hline & Incorporation $\%$ & $\begin{array}{c}\text { Dry Matter } \\
(\mathrm{Kg})\end{array}$ & Incorporation $\%$ & Dry Matter (Kg) \\
\hline Wheat straw & 4,52 & 0,66 & 4,89 & 0,66 \\
\hline Corn silage & 12,05 & 0,56 & 27,69 & 1,19 \\
\hline Hydroponic barley & 21,08 & 0,455 & 0 & 0 \\
\hline Flaked corn & 13,55 & 2,025 & 14,66 & 2,025 \\
\hline BPM Fattening & 9,94 & 1.462 & 10,75 & 1,462 \\
\hline BP Beef & 5,12 & 0,752 & 5,54 & 0,752 \\
\hline Bacterial & 3,01 & 0.35 & 3,26 & 0,35 \\
\hline Return Milk & 16,57 & 0,413 & 17,92 & 0,423 \\
\hline Citrus pulp & 14,16 & 0,47 & 15,31 & 0,47 \\
\hline Dry matter (\% DM) & \multicolumn{2}{|c|}{43,05} & \multicolumn{2}{|c|}{47,7} \\
\hline Crude Protein $(\%)$ & \multicolumn{2}{|c|}{16,06} & \multicolumn{2}{|c|}{16,8} \\
\hline Meat Fodder Unit (UF/Kg DM) & \multicolumn{2}{|c|}{0,95} & \multicolumn{2}{|c|}{0,94} \\
\hline Acid Detergent Fiber (\% DM) & \multicolumn{2}{|c|}{13,76} & \multicolumn{2}{|c|}{14,32} \\
\hline Neutral Detergent Fiber (\% DM) & \multicolumn{2}{|c|}{26,53} & \multicolumn{2}{|c|}{28,44} \\
\hline Total Nitrogenous Matter (\% DM) & \multicolumn{2}{|c|}{16,8} & \multicolumn{2}{|c|}{16,06} \\
\hline Materials Minerals (\% DM) & \multicolumn{2}{|c|}{5,05} & \multicolumn{2}{|c|}{4,78} \\
\hline Calcium (g/Kg DM) & \multicolumn{2}{|c|}{5,93} & \multicolumn{2}{|c|}{5,08} \\
\hline Phosphor (g/Kg DM) & \multicolumn{2}{|c|}{3,16} & \multicolumn{2}{|c|}{3,09} \\
\hline
\end{tabular}




\section{2-5 Statistical analysis}

The data were entered into Excel 5.0 software, which made it possible to express the results as an average \pm standard deviation. The collected data were subjected to ANOVA analysis of variance, for all the studied parameters using the $\mathrm{R} v$ 3.2.5 software.

\section{3- Results and Discussion}

Figure 1 highlights the two batches of bull calves having 50 heads each: the control batch and the Hydroponic Barley (HB) batch. At the start of the test, a weight difference of $7 \mathrm{Kg}$ was observed between the two batches in favor of the HB batch. Over the test period, the HB batch obtained a growth of $239.02 \mathrm{~g} / \mathrm{d}$ against $251.77 \mathrm{~g} / \mathrm{d}$ for the control batch.

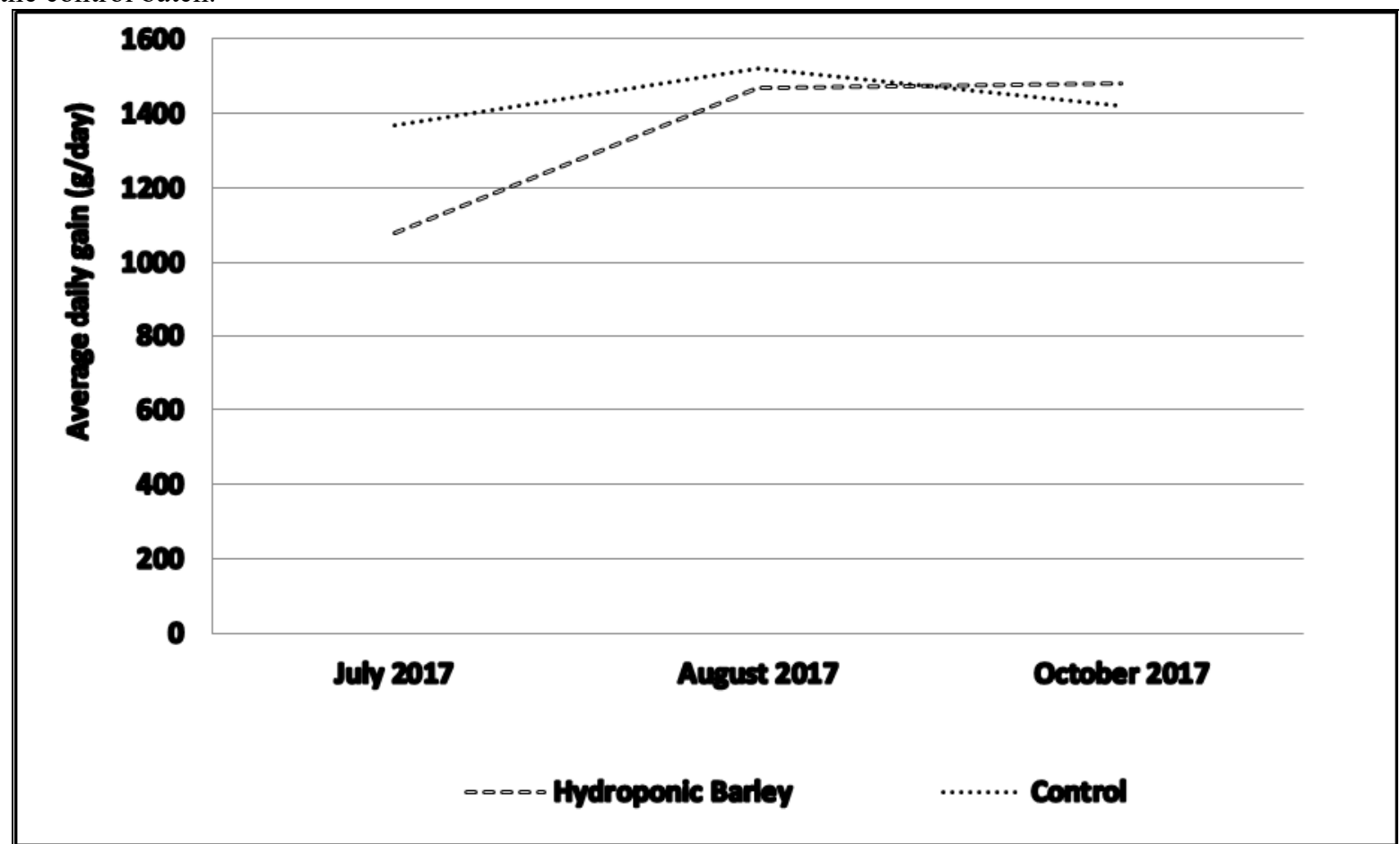

Figure 1: Growth comparison of the control and hydroponic barley batches

The graph shows two curves and therefore two changes in terms of average weight gain, almost similar for the two batches. However, during the finishing phase, i.e. the period covering the months of September and October, we noted a higher average daily gain for the batch fed with a diet enriched in HB. In fact, the average daily gain for this batch amounts to $1.48 \mathrm{Kg}$ /day compared to $1.42 \mathrm{Kg} / \mathrm{Day}$ for the control batch.

It should also be noted that the gain for the control batch decreases during this same phase, going from 1.52 to $1.42 \mathrm{Kg} /$ Day, while the other batch benefiting from a diet enriched with HB registers a slight increase in terms of weight gain from $1.47 \mathrm{Kg} /$ Day to $1.48 \mathrm{Kg} /$ Day.

We thus conclude that the introduction of hydroponic barley has a positive impact in the $3^{\text {rd }}$ phase of calves' fattening which corresponds to the finishing phase.

The final live weights were $500.02 \pm 17,6$ and $505.77 \pm 14,9 \mathrm{Kg}$, and the total body weight gain during the 175-day experimental period averaged $1364,08 \pm 8,31$ and $1422,43 \pm 7,42 \mathrm{Kg}$ respectively for the $\mathrm{HB}$ and Control groups. Therefore, these weights do not turn out to be significantly different for the two groups.

Furthermore, when the daily live weight gain was calculated from the changes in the body weight per month, we did not find any significant monthly difference for the calves receiving both the control and HB diets. However, calves fed with the control diet showed numerically higher means of daily gain during the experimental period compared to those fed with green fodder $\left(1422.43\right.$ vs. $1364.08 \mathrm{~g} \mathrm{~d}^{-1}(\mathrm{p}>0.05)$. The consumption indices, during the test phase, are equivalent: 6.83 and $6.14 \mathrm{Kg} \mathrm{DM} / \mathrm{Kg} \mathrm{OF}$ bright weight respectively for the control and the test batches (Table 2). 
Table 2: Effect of treatments on the animal performance

\begin{tabular}{|l|c|c|c|}
\hline \multirow{2}{*}{ Animal performance } & \multicolumn{2}{c|}{ Dietary groups } \\
\cline { 2 - 4 } & Hydroponic Barley & Control & p-value \\
\hline Initial Weight (Kg) & $261 \pm 16.80$ & $254 \pm 13.16$ & 0,9724 \\
\hline Final weight (Kg) & $500.02 \pm 17,60$ & $505.77 \pm 14,90$ & 0,8890 \\
\hline Average daily gain (g/Day) & $1364,08 \pm 8,31$ & $1422,43 \pm 7,42$ & 0,4120 \\
\hline $\begin{array}{l}\text { Feed conversion ratio (Dry matter intake }(\mathrm{Kg}) / \mathrm{Kg} \text { of live } \\
\text { weight gain) }\end{array}$ & $6,14 \pm 0,02$ & $6,83 \pm 0,03$ & 0,5264 \\
\hline Slaughter live weight (Kg) & $543,00 \pm 45,91$ & $538,85 \pm 70,49$ & 0,7312 \\
\hline Carcass weight (Kg) & $305.78 \pm 28,64$ & $305.52 \pm 47,97$ & 0,9741 \\
\hline Carcass yield (\%) & $56,28 \pm 0,01$ & $56,55 \pm 0,02$ & 0,4785 \\
\hline
\end{tabular}

At slaughter, the tests on feedlot calves show that the HB batch obtains an average carcass weight of 543.00 $\pm 45.91 \mathrm{Kg}$, against $538.85 \pm 70.49 \mathrm{Kg}$ for the control batch. There is therefore a difference of $4.15 \mathrm{Kg}$, which is not statistically significant and corresponds to a gain of $0.8 \%$ compared to the control batch. The carcass yield of the HB batch was $56.28 \pm 0.01 \%$, compared to $56.55 \pm 0.02 \%$ for the control batch. We can legitimately conclude that there is no differentiation between the batches in terms of live weight, carcass weight, and carcass yield. Due to the lack of a certified pointer, we were unable to assess the quality of the carcasses.

In addition, the chemical composition of food shows that hydroponic barley has a low dry matter content (13\%) compared to that of grains (88\%). Its composition appears in fact to be highly dependent on the initial seed and the cultivation conditions. However, the germination of barley increased the contents of MAT $(14.4 \%$ $\mathrm{DM})$ and NDF (58.3\%), without modifying the OM content.

According to the literature (Morgan et al., 1992; Sneath and McIntosh, 2003), hydroponic barley represents a particularly nutritious food for ruminants, and it is very rich in vitamins which could activate certain enzymes (during germination) and transform starch, proteins, and lipids to simpler forms, thus influencing the animals' performance (Mayer and Poljakoff-Mayber, 1975; Kruglyakov, 1989). Feeding of hydroponics fodder increases also the digestibility of the nutrients of the ration which could contribute towards increase in milk production (Naik et al., 2015)

Live weight gain depends on several factors such as breed characteristics, age, initial bodyweight, nutrition, and management practices (Baker et al., 2002; Restle et al., 2003; Berry et al., 2003; Berry et al. al., 2004).

In our study, these factors were controlled in a similar way for the two groups of animals. Therefore, the introduction of hydroponic green fodder reveals an advantage in terms of daily weight gain for calves in the $3^{\text {rd }}$ fattening phase which corresponds to the finishing phase.

Our results differ somewhat from those observed by Miralles-Bruneau et al., (2015) who carried out a test on two batches of 6 young crossbred cattle, over a fattening period of 203 days in order to evaluate the effects of the hydroponic barley introduction. In the finishing phase, a better $\mathrm{pH}$ stability of the Hydroponic barley batch was observed, following a sudden change in base forage. Miralles-Bruneau et al., (2015) observed similar growth performance for the two batches, which can easily be explained by equivalent rationing. The slaughter results differ somewhat, with a slightly higher carcass yield in favor of the control batch $(+2 \%)$, a trend that can be found in the other trials, and a conformation of the carcasses turns out to be a third of a class better.

In a comprehensive review of hydroponic fodder versus beef cattle, several research works were conducted to assess the nutritional value of sprouted grain. The researchers found that beef cattle fed with hydroponic green fodder obtained an average daily gain of $200 \mathrm{~g}$ compared to those fed with a control corn diet (Leitch, 1939). Same results where described by Rajkumar et al. (2018) which indicates a body weight gain of crossbred calves after substitution of feeding of hydroponics maize fodder of calf starter.

The literature also highlights improvements in performance when the supplement provides the major limiting nutrient (s) or improves the efficiency of food use. In this regard, we can cite the work of Tudor et al. (2003) who performed the steers experiment on protein-deficient hay. They highlighted an improvement in the efficiency of use of low-protein hay, with a greater growth than that expected in fattening young bull calves, given the ingested energy and protein intake. Tudor et al. (2004) have also tested a ration based on hay and hydroponic barley of 6-7 days (20-37\% of the ration), on 20 young fattened calves during a 70 day period. They observed a higher average weight gain than expected given the nutritional contribution provided by this ration. They found that steers fed a restricted hay diet with $1.8 \mathrm{Kg}$ of MS barley germ over 48 days, gained 1 $\mathrm{Kg} / \mathrm{Head} /$ Day of live weight. The same cattle fed an additional 22 days, receiving $1.5 \mathrm{Kg} \mathrm{DM}$ of barley sprouts and hay at will, gained $0.41 \mathrm{Kg} / \mathrm{Head} / \mathrm{Day}$. The authors explain these performances by a better efficiency of the ration use by the animal, due to the contribution of soluble nutrients by the hydroponic barley, which are quickly assimilated and come from an enzyme complex

Hydroponic green fodder also makes it possible to offset the negative effects (weight loss, drop in milk production) linked to a sudden change in the quality of fodder or meadows by providing a quality base constant 
(Rodrigues-Muela et al., 2005).

Espinoza et al. (2004) also observed a higher and more constant average daily gain on a batch of bull calves fed with $30 \%$ of hydroponic green fodder, whose basic ration consisted of cut grass low in protein and with a varied composition every week.

According to Bari et al. (2020) study on the effect of hydroponic barley feeding on the productive performance of goats, there is a faster growth performance when consuming hydroponic barley by males (up to $30 \%$ ) and females (up to 38\%) at different ages. These results clearly underline that hydroponic barley represents an advantageous alternative for farmers wishing to increase and boost the performance of their goat livestock and thus show an improvement in growth performance thanks to the use of hydroponic green fodder for lambs' feeding. Therefore, local farmers are recommended to use hydroponic barley as an alternative fodder for lambs and other livestock to improve their growth performance and during the fattening period (Ata, 2016).

Research carried out by Bari et al. (2019) also emphasizes that innovation has a negative influence on the financial structure but it has no influence on the financial performance. These data can be explained by the short duration of the project (only 2 years of experience). This is indeed a period during which companies often have high financial needs. It is important to note, however, that the cooperative shows an encouraging financial and commercial profitability, despite the unfavorable economic conditions.

According to Farghaly et al. (2019), hydroponically sprouted fodder are rich in nutrient content which have better digestibility, ruminal enzyme activities as well as fermentation. Moreover, the use of sprouted barley in sheep diets could result in better digestibility and fermentation results than the clover. Thus, it can be recommended to feed the hydroponic barley sprouts with the concentrate to obtain an optimal DM intake as well as a high animal performance

In order to be as complete as possible, we need to qualify our statements. Indeed, the experiments carried out by Sneath and McIntosh (2003), reveal that hydroponic barley probably does not have a higher bioavailability of nutrients for calves' fattening. The authors report that "most trials of livestock performance using hydroponic sprouts show no benefit from including them in the diet, especially when they replace highly nutritious foods such as grain."

In a trial carried out by Fazaeli et al. (2011), focusing on the performance of male calves in a feedlot fed with hydroponic green fodder and having obtained a body weight gain of $200 \mathrm{~g}$ /day, the authors do not find any significant difference in the weight gain or the feed conversion efficiency between a fodder diet and a control diet, consisting of barley grains. They conclude that, given the costs associated with grain germination and DM losses, it is not recommended to feed the hydroponic barley calf with feedlot calves.

Farlin et al. (1970) found no difference in cattle fed with sprouted or non-germinated seeds; the daily weight gain in the T0 treatment was actually a loss of $-1.17 \mathrm{~g} /$ Day due to a low content of protein and a reduced appetite with millet straw.

\section{4- Conclusion}

We note from all the afore mentioned works, that hydroponic green fodder is of no interest when the animal has at its disposal either qualitatively or quantitatively sufficient natural fodder. On the other hand, when the fodder does not appear to be available in sufficient quantity and / or quality (in particular protein content), hydroponic green fodder is of certain interest due to the consistency of its quality, thus ensuring regular growth for the livestock.

Given the current cost of this fodder, it does not also necessarily seem appropriate to give it throughout the fattening; it should be focused on key phases. This is indeed a fodder which a priori could be interesting in fattening/finishing, thanks to its balanced PDIE/PDIN value, despite a somewhat low UF value. It could be added to the growth ration, from $450-500 \mathrm{Kg}$ live weight. It remains to be defined how high it can be added to the ration and with what supplement, with the aim of achieving a fair technical and economic balance.

The results of our study suggest that hydroponic barley based rationing remains to be investigated, in particular for its effects on rumen functioning and on the efficiency of ration use. It would be desirable to repeat the experiment by testing different levels of hydroponic barley intake, adjusting the type and level of supplementation, with more precise monitoring of the diet. It also seems interesting to repeat the test with other types of fodder.

\section{5- References}

AOAC. (2000). Official Methods of Analysis. 17thEd.Association of Official Analytical Chemists, Gaithersburg, $M D$

Ata Mysaa (2016). Effect of hydroponic barley fodder on awassi lambs performance. Journal of Biology, Agriculture and Healthcare, Vol.6, No.8, pp 60-64.

Baker, D. H., A. B. Batal, T. M. Parr, N. R. Augspurger, and C.M. Parsons. (2002). Ideal ratio (relative to lysine) of tryptophan, threonine, isoleucine, and valine for chickens during the sec-ond and third weeks posthatch. 
Poult. Sci. 81:485-494.

Bari I., S. Bari, A. Kaaya et H. Mannas (2019). Innovation, performance financière et entrepreneuriat coopératif : Quels liens ? Cas de la culture hydroponique de l'orge au sein de la Coopérative Ait Si Salem. International Journal of Business \& Economic Strategy (IJBES), Vol 12, pp 1-7.

Bari S., Hikamat A., Kaaya A., El Moukhtari A. and Mannas H. (2020). Use of hydroponic green fodder in sheep meat breeding and production in the Souss Massa Region (South of Morocco): Preliminary study. International Journal of Agriculture, Environment and Bioresearch, Jan-Feb 2020, Volume 5, Issue 1, pp 329-336.

Berry, D. P., F. Buckley, P. Dillon, R. D. Evans, M. Rath, and R. F. Veerkamp. (2003). Genotype x environment interaction of milk yield, body condition score, and body weight in a grass based system using random regression models. Livest. Prod. Sci. 83: pp 191-203.

Berry DP, Buckley F, Dillon PG, Evans RD and Veerkamp RF (2004). Genetic relationships among linear type traits, milk yield, body weight, fertility and somatic cell count in primiparous dairy cows. Irish Journal of Agricultural \& Food Research, 43, pp 161-176.

Bakshi M. P. S., M. Wadhwa and Harinder P. and S. Makkar (2017). Hydroponic fodeers production: A critical assessment. Broadening Horizons, December 2017, 48 (2), pp 1-10, Feedipedia.

Chavan, J. and Kadam, S.S. (1989). Nutritional improvement of cereals by sprouting. Critical Reviews in Food Science and Nutrition, 28: pp 401-437.

Dung, D.D., Godwin, I.R. and Nolan, J.V. (2010). Nutrient content and in sacco degradation of hydroponic barley sprouts using nutrient solution or tap water. Journal of Animal and Veterinary Advances, 9: pp 24322436.

Espinoza, F., P. Argenti, G. Urdaneta, C. Araque, A. Fuentes, J. Palma y C. Bello. (2004). Uso del forraje de maíz (Zea mays) hidropónico en la alimentación de toretes mestizos. Zootecnia Trop., 22(4): 303-315.

Farghalya Mohsen M., Mahmoud A.M. Abdullaha, Ibrahim M.I. Youssef, Ismail R. Abdel-Rahim, Khaled Abouelezz (2019). Effect of feeding hydroponic barley sprouts to sheep on feed intake, nutrient digestibility, nitrogen retention, rumen fermentation and ruminal enzymes activity. Livestock Science, Volume 228, pp 31-37.

Farlin, S. D., Dahmen, J. J. and Bell, T. D. (1971). Effect of Sprouting on Nutritional Value of Wheat in Cattle Diets. Can. J. Anim. Sci., 51(1): pp 147-151.

Fazaeli, H., Golmohammadi, H.A., Shoayee, A.A., Montajebi, and S. Masharaf. (2011). Performance of feedlot calves fed hydroponics fodder barley. Journal of Agricultural Science and Technology, 13: pp 367-375.

Finney, P. L. (1982). Effect of germination on cereal and legume nutrient changes and food or feed value. $A$ comprehensive review. recent advances in phytochemistry, 17: 229-305.

Gebremedhin W.K., B.G. Deasi and A.J. Mayekar (2015). Nutritional Evaluation of Hydroponically Grown Barley Fodder. Journal of Agricultural Engineering and Food, Volume 2, Number 2; April-June, 2015 pp. 86-89.

Indira D., P Aruna, S Swetha Kanthi and K Kumar (2020). Hydroponics as an alternative fodder for sustainable livestock production. World Journal of Advanced Research and Reviews. 05(02), pp 87-92.

João Restle, Paulo Santana Pacheco, José Luiz Moletta, Ivan Luiz Brondani, Liliane Cerdótes (2003). Grupo genético e Nível nutricional pós-parto na produção e composição do leite de vacas de corte. R. Bras. Zootec., Vol.32, N³, p.585-597.

Kruglyakov and Yu. A. (1989). Construction of Equipment for Growing Green Fodder by a Hydroponic Technique. Traktory-I Sel'skokhozyaistvennye Mashiny, 6(1):24-27.

Kumar Balwinder, Navjot Singh Brar, H. K. Verma, Anil Kumar and Rajbir Singh (2019). Nutritious feed for farm animals during lean period: silage and hay-a review. Forage Res., 45 (1) : pp. 10-22.

Leitch, I. (1939). Sprouted Fodder and Germinated Grain in Stock Feeding. Technical Communi., 11(1): pp 3-63.

Mayer A. M. and Poljakoff-Mayber A. (1975). The Germination of Seeds, Elsevier Science \& Technology, Volume 80189652, 192 pages.

Maëva Miralles-Bruneau, Charles-Emile Bigot, David Forget, David Grangette and Mickael Payet. Jean-Luc Benard, Sao Barreira, David Forget, David Rangette, Samuel Grondin, Alex Michon, Mickael Payet, Yoann Pellier, Anne-Marie Picard, Guy-Noël Picard, Jean-Philippe PIcard, Tony Picard, Jean-Louis Reboule et Dominique Valin (2015). Utilisation du fourrage vert hydroponique en production de viande bovine et ovine à la Réunion. Projet Sica Révia. 85 pages.

Morgan, J., Hunter, R. R., and O' Haire, R. (1992). Limiting factors in hydroponic barley grass production. Proceeding of the $8^{\text {th }}$ International Congress on Soil Less Culture, Hunter's Rest, South Africa. 2-9 October 1992, pp 241-261.

Mayer, A. M. and Poljakoff-Mayber, A. (1975). The germination of seeds. $2^{\text {nd }}$ Edition, Pergamon Press, Toronto.

Naik P.K., B.K. Swain and N.P. Singh (2015). Production and utilisation of hydroponics fodder, Review. Indian J. Anim. Nutr. 32 (1): 1-9. 
Pandey, H. N. and Pathak, N. N. (1991). Nutritional evaluation of artificially grown barley fodder in lactating crossbred cows. Indian J. Anim. Nutr. 8 (1): pp 77-78.

Peer, D. J. and Lesson, S. (1985). Feeding Value of Hydroponically Sprouted Barley for Poultry and Pigs. Anim. Feed Sci. Technol., 13(3-4): pp 183-190.

Rajkumar G., M.T. Dipu, K. Lalu, K. Shyama and P.S. Banakar (2018). Evaluation of hydroponics fodder as a partial feed substitute in the ration of crossbred calves. Indian J. Anim. Res., 52(12): pp 1809-1813.

Rodriguez-Mulea, C., Rodriguez, H. E., Ruiz, O., Flores, A., Grado, J. A. and Arzola, C. (2004). Use of green fodder produced in hydroponic system as supplement for lactating cows during the dry season. Proceeding of American Society of Animal Science, 56: pp. 271-274. (Western Section).

Robertson J.B. and Van Soest P.J. (1981). The detergent system of analysis. In: James, W.P.T., Theander,O. (Eds.). The Analysis of Dietary Fiberin Food. Marcel Dekker, NY, pp. 123-158.

Sharma Nisha, Somen Acharya, Kaushal Kumar, Narendra Singh and O.P. Chaurasia (2019). Hydroponics as an advanced technique for vegetable production: An overview. Journal of Soil and Water Conservation 17(4): pp 364-371.

Shipard, I. (2005). How can I grow and use sprouts as living food. Stewart Publishing, 136 pages.

Sneath, R. and F. McIntosh. (2003). On farm review of hydroponic fodder production for beef cattle. Meat and Livestock Australia Limited, Locked Bag 991, North Sydney NSW 2059, ABN 39081678 364, ISBN 1 74036503 8, pp 1-54.

Tudor, G., Darcy, T., Smith, P. and Shallcross, F. (2003). The intake and live weight change of drought master steers fed hydroponically grown, young sprouted barley fodder (Auto Grass). Department of Agriculture Western Australia.

Tudor G., D., Darcy T., Smith P., C., Shallcross F., Allen J., G. (2004). Is there a Role for Hydroponics in the Beef Industry? Animal Production in Australia, 25:233.

Van Soest, P. J., Robertson, J. B. and Lewis, B. A. (1991). Methods of dietary fiber, neutral detergent fiber and non-starch polysaccharides in relation to animal nutrition. J. Dairy Sci., 74: pp 3583-3597. 